\title{
ACUTE INTRAVENOUS ADMINISTRATION OF POTASSIUM CHLORIDE TO FUROSEMIDE PRETREATED DOGS
}

\author{
K.C. Wong, Ryohei Kawamura, Michael R. Hodges and Shaun P. Suldivan
}

Proper balance of electrolyte concentrations between the intracellular and extracellular spaces is essential for the normal electrophysiologic functions of excitable cells. ${ }^{1}$ Potassium plays an especially important role in maintaining the resting membrane potential and in repolarization of excitable cells. Thus it has received attention as one of the major causes of cardiac dysrhythmias during anaesthesia. Since it is impractical, if not impossible, to measure the intracellular concentration of electrolytes clinically and estimates of total body potassium by radioisotope dilution technique are not widely available, one must rely upon plasma electrolyte measurements for assessment of the total body electrolyte content. "Hypokalaemia" is a term used clinically to describe a reduction in serum potassium concentration, but it is frequently equated with a loss of total body potassium, which may not be true. In the present report, "hypokalaemia" will only refer to a reduction in serum potassium. Sodium is the predominant cation in the extracellular space, but plasma potassium only represents about 1.4 per cent of the total body potassium. ${ }^{2}$ Furthermore, plasma $\mathrm{K}^{+}$is labile; hypokalaemia can be acutely induced by alkalosis, anaesthetics and skeletal muscle relaxants. ${ }^{3}$ Therefore, plasma potassium may not be a reliable index of total body potassium content.

It is not uncommon to anaesthetize a hypokalaemic patient who has been subjected to chronic diuretic treatment. In emergency situations, it is sometimes necessary to administer intravenous potassium to such a patient until the plasma potassium level has reached acceptable values. It is unclear what is a safe rate of intravenous potassium administration and how effective acute administration is for repletion of reduced body potassium. The present study evaluates the plasma potassium and sodium changes associated with daily intravenous administration of furosemide in dogs. Intravenous potassium chloride was then administered to untreated and furosemide-pretreated dogs and observations were made on serum and urinary levels of potassium and sodium as well as effects on the cardiovascular system.

K.C. Wong, M.D., Ph.D., Professor and Chairman of Anesthesiology; Associate Professor of Pharmacology; Ryohei Kawamura, M.D., Assistant Professor of Anesthesiology; Michael R. Hodges, Technical Research Supervisor; Shaun P. Sullivan, B.S., Research Assistant.

A portion of this data was presented at the Canadian Anaesthetist Society Meeting, Montreal, Canada, June 21-24, 1976.

This study was supported by grants from the University of Utah Dean's Research Fund and the Utah Heart Association.

From the Departments of Anesthesiology and Pharmacology, the University of Utah College of Medicine, 50 North Medical Drive, Salt Lake City, Utah, 84132. 


\section{MEthods}

Twelve male mongrel dogs weighing $17.5-29.0 \mathrm{~kg}$ were used for this study; six were untreated (control) and six were given intravenous furosemide $(1 \mathrm{mg} / \mathrm{kg}$ ) daily for at least seven consecutive days before each study. Each animal was studied three times and intravenous $\mathrm{KCl} 0.8,1.6$ or $3.2 \mathrm{mMol} / \mathrm{kg} / \mathrm{hr}$ was administered by a Harvard infusion pump for one hour to all animals. Only one dose for each study and at least 7 days were allowed between studies. The total dose of $\mathrm{KCl}$ was usually contained in $40 \mathrm{ml}$ of saline. During the initial study, the animal received randomly $\mathrm{KCl} 0.8$ or $1.6 \mathrm{mMol} / \mathrm{kg} / \mathrm{hr}$; the $3.2 \mathrm{mMol} / \mathrm{kg} / \mathrm{hr}$ dose was lethal, thus was always given during the third study. Daily plasma $\mathrm{Na}^{+}$and $\mathrm{K}^{+}$levels were determined in all furosemide-treated animals with the use of an IL 143 flame photometer.

Unmedicated dogs were given thiopentone $15-20 \mathrm{mg} / \mathrm{kg}$ to facilitate tracheal intubation and mechanical ventilation, maintaining $\mathrm{Pa}_{\mathrm{CO}_{2}}$ of 4.0 to $4.5 \mathrm{kPa}$ (30-35 torr). Inhalation anaesthesia was with $\mathrm{N}_{2} \mathrm{O}-\mathrm{O}_{2}$ ( 60 per cent-40 per cent) and halothane ( 1 per cent). Catheters were inserted percutaneously into the saphenous vein and femoral artery from which continuous pressure and periodic plasma $\mathrm{Na}^{+}$ and $\mathrm{K}^{+}$and blood gases were monitored. $\mathrm{A}$ catheter was also inserted into the bladder for urinary volume, $\mathrm{Na}^{+}$and $\mathrm{K}^{+}$measurements. Lactated Ringer's solution was infused to all dogs at the rate of $10-15 \mathrm{ml} / \mathrm{kg} / \mathrm{hr}$.

The arterial pulse contour was fed into a computer substation and analyzed to provide cardiac output, stroke volume, heart rate, mean arterial pressure and peripheral resistance by the method of Warner. ${ }^{4}$ Lead II of the ECG and rectal temperature were continuously monitored.

When the cardiovascular parameters had stabilized after 45-60 minutes, serum $\mathrm{Na}^{+}$and $\mathrm{K}^{+}$and urinary $\mathrm{Na}^{+}$and $\mathrm{K}^{+}$were determined. The calculated dose of potassium chloride was then infused intravenously over a one-hour period by a Harvard syringe pump through a separate catheter placed in a forelimb vein. Serum $\mathrm{Na}^{+}$and $\mathrm{K}^{+}$were determined every 15 minutes during and following $\mathrm{KCl}$ infusion until the serum electrolyte levels had returned to control or until the animal had expired from an overdose of $\mathrm{KCl}$ (i.e. $3.2 \mathrm{mMol} / \mathrm{kg} / \mathrm{hr}$ ). Arterial blood gases, urinary volume and urinary $\mathrm{Na}^{+}$and $\mathrm{K}^{+}$were determined every 30 minutes.

Statistical analysis was done using Student's t-test for paired and unpaired data. A probability of $\mathrm{P}<0.05$ was considered significant.

TABLE I

Daily Plasma Levels in Dogs During Furosemide $(1 \mathrm{mg} / \mathrm{kg}$ ) Treatment, MEAN $\pm \mathrm{SE}, \mathrm{N}=18$

\begin{tabular}{lccccccc}
\hline \hline & \multicolumn{7}{c}{ Days } \\
\cline { 2 - 8 } & 1 & 2 & 3 & 4 & 5 & 6 & 7 \\
\hline $\mathrm{Na}$ & 142.5 & 143.6 & 144.2 & 144.2 & 144.0 & 142.8 & 143.6 \\
$\mathrm{mMol} / 1$ & \pm 1.0 & \pm 1.1 & \pm 1.1 & \pm 1.0 & \pm 1.0 & \pm 1.0 & \pm 0.7 \\
$\mathrm{~K}$ & 4.48 & 4.27 & $4.10^{*}$ & $4.13^{*}$ & $4.09^{*}$ & $4.13^{*}$ & $4.18^{*}$ \\
$\mathrm{mMol} / 1$ & \pm 0.07 & \pm 0.07 & \pm 0.07 & \pm 0.05 & \pm 0.06 & \pm 0.05 & \pm 0.06 \\
\hline
\end{tabular}

${ }^{*} \mathrm{P}<0.01$, Significantly different from Day 1 . 


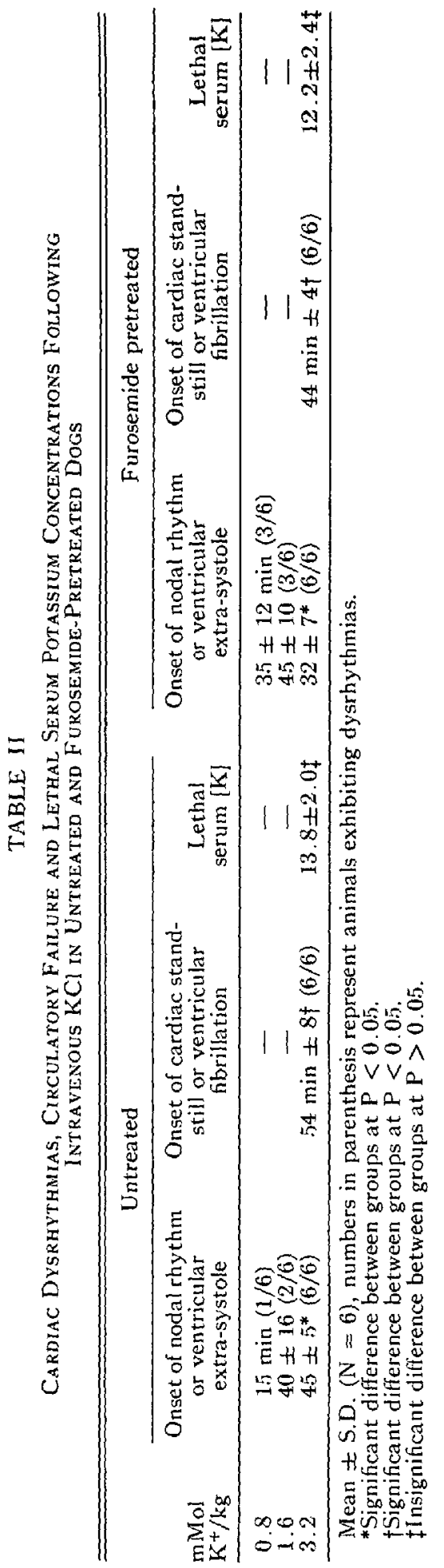




\section{RESULTS}

Daily administration of furosemide $(1 \mathrm{mg} / \mathrm{kg}$ ) produced a small but significant reduction in serum potassium from 4.48 to a low of $4.09 \mathrm{mMol} / 1(\mathrm{P}<0.01)$ with no significant change in serum sodium (Table I). During intravenous administration of $\mathrm{KCl} 3.2 \mathrm{mMol} / \mathrm{kg} / \mathrm{hr}$ there was a reduction in the time to onset of nodal rhythm and/or ventricular extrasystoles (Table II) in the furosemide pretreated animals. The usual ECG changes of acute hyperkalaemia were observed and were not distinguishable in the untreated from the furosemide-pretreated animals, but the number of animals exhibiting dysrhythmias was increased in the latter group. Intravenous $\mathrm{KCl} 3.2 \mathrm{mMol} / \mathrm{kg}$ was lethal in all animals, but the furosemide animals tended to succumb at a lower serum potassium concentration (12.2 vs 13.8 $\mathrm{mMol} / 1, \mathrm{P}>0.05$ ) with an earlier onset of circulatory failure (44 vs $54 \mathrm{~min}$, $\mathrm{P}<0.05)$.

Cardiac output, heart rate and mean arterial pressure tended to increase in all animals following administration of $\mathrm{KCl}$ but changes only became statistically significant when the serum $\mathrm{K}^{+}$was $6.9-9.1 \mathrm{mMol} / 1$. No statistically significant changes were observed for stroke volume and peripheral resistance. Arterial blood gases remained stable throughout the studies.

There was no significant difference between peak serum potassium levels of untreated and furosemide-pretreated dogs when comparing like-doses of $\mathrm{KCl} 0.8$ or $1.6 \mathrm{mMol} / \mathrm{kg}$ infused (Figure 1). Urinary excretion of potassium tended to increase with increased $\mathrm{KCl}$ infusion, but there were no statistically significant differences of total urinary potassium excretion between the untreated and furosemide-pretreated groups when like-doses of $\mathrm{KCl}$ were infused (Figure 1). Total urine output tended to be lower in the furosemide-pretreated group infused with $\mathrm{KCl} 0.8 \mathrm{mMol} / \mathrm{kg}$.

\section{Discussion}

Of the total body potassium of approximately $3500 \mathrm{mMol}$ in a $70 \mathrm{~kg}$ man only $50 \mathrm{mMol}$ or 1.4 per cent is in the extracellular space providing a serum $\mathrm{K}^{+}$concentration of $4 \mathrm{mMol} / 1 .^{2}$ Accordingly, if $50 \mathrm{mMol}$ of intracellular $\mathrm{K}+$ moved into the extracellular space, serum $\mathrm{K}^{+}$concentration would double; and if half the extracellular $\mathrm{K}^{+}$moved into cells, serum $\mathrm{K}$ concentration would fall to half its value but cell $\mathrm{K}^{+}$concentration would increase by only 0.7 per cent.

Serum $\mathrm{K}^{+}$concentration represents the equilibrium established between intracellular and extracellular $\mathrm{K}^{+}$as well as potassium intake and output. Wong, et al. ${ }^{3}$ have shown that acute hypokalaemia can be induced in dogs by respiratory alkalosis, anaesthetics and non-depolarizing neuromuscular blocking agents. However, this acutely induced hypokalaemia did not appear to be detrimental to the cardiovascular system or to cardiac excitability, ${ }^{5}$ probably because there was no true loss of body potassium, but only redistribution of potassium between body compartments. In contrast, patients taking digitalis and diuretics were prone to develop cardiac dysrhythmias induced by respiratory alkalosis and hypokalaemia. ${ }^{6,7}$ Thus, it has been postulated that true loss of body potassium is more serious for the development of cardiac dysrhythmias in anaesthetized patients. 
WONG, et al.: INTRAVENOUS KCL AND HYPOKALEMIA
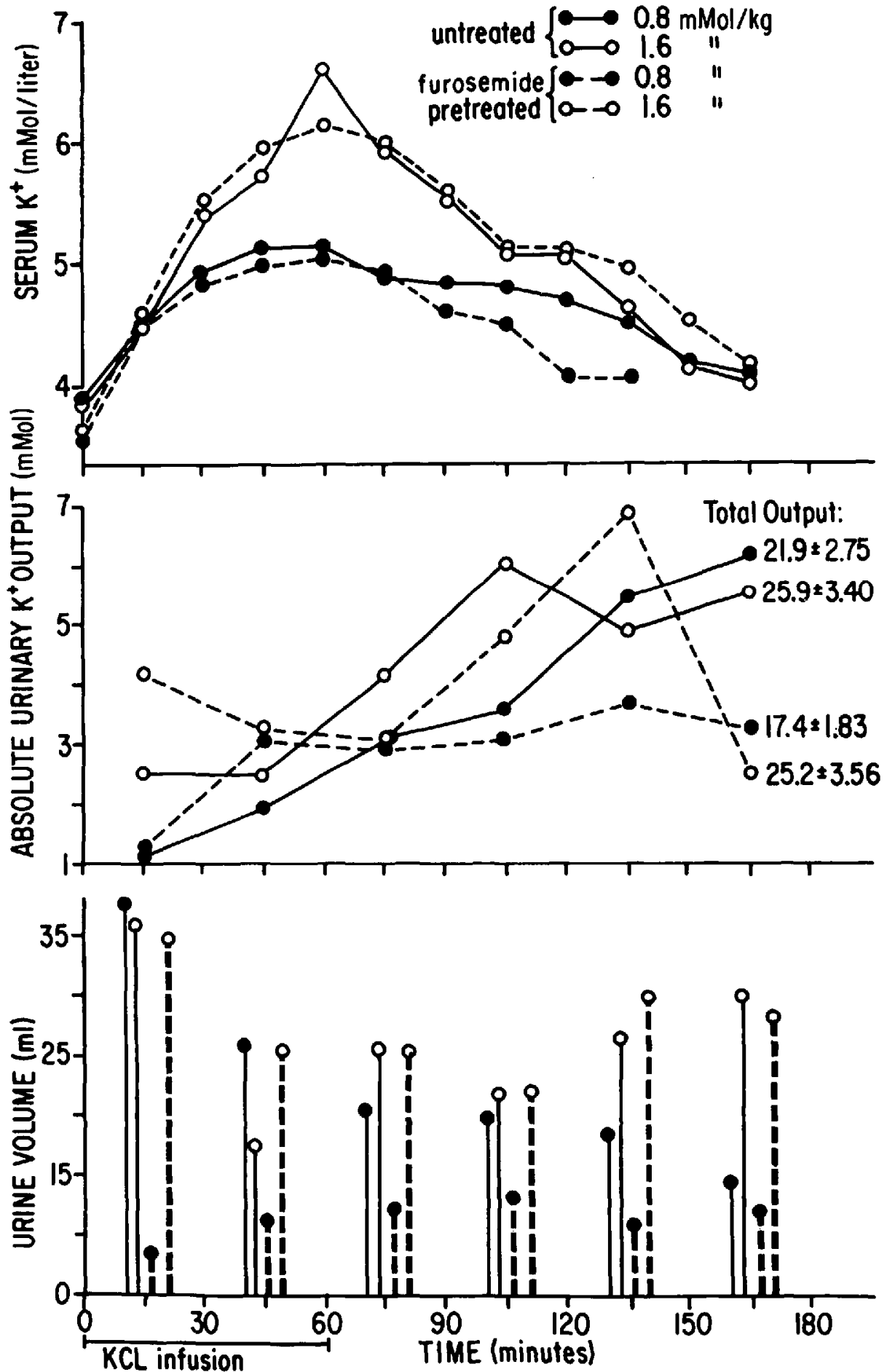

Figure 1. Effect of intravenous potassium chloride on serum potassium, urinary volume and potassium output. 
Hyperkalaemia is a common finding in patients with chronic renal failure, representing a decrease in renal output of $\mathrm{K}^{+}$. These patients tolerate chronically elevated serum potassium concentrations, which if acutely achieved in normal patients, could produce serious cardiac dysrhythmias. A proper potassium gradient between intra- and extra-cellular compartments seems to play an important role in maintaining cardiac stability. Serum potassium, by itself, is not a reliable estimate of total body potassium. However, combined with a reliable history, serum potassium is still a practical and valuable clinical tool for patient care.

The mechanism of furosemide-induced diuresis is not completely understood; inhibition of renal Na-K ATPase ${ }^{8,9}$ and adenyl cyclase ${ }^{10}$ has been implicated. The important site of action has been identified as the ascending loop of Henle and the most distal diluting segments located in the renal cortex. ${ }^{11}$ The filtrate presented to the sodium-potassium ion exchange site in the distal tubule is increased in volume and total sodium content with a consequent acceleration in the rate of ion exchange and a marked kaliuresis. Hypokalaemia is common in patients on chronic furosemide therapy.

Our data show that furosemide pretreatment produced a small but significant reduction in serum potassium from 4.48 to a low of $4.09 \mathrm{mMol} / \mathrm{l}$ in dogs on a normal diet; although statistically significant it certainly does not represent a hypokalaemic level which might be considered clinically dangerous. However, these furosemide-pretreated dogs were more sensitive to intravenous $\mathrm{KCl}$ as far as development of cardiac dysrhythmias and circulatory failure are concerned.

There are two possibilities to explain the furosemide increased cardiac instability to intravenous potassium: (1) The rate and the concentration of change of extracellular potassium have a profound effect on the electrophysiology of the cardiac cell. A rapid increase from low to normal serium potassium levels in the isolated heart preparation ${ }^{12}$ or in hypokalaemic dogs ${ }^{13}$ shortens duration of the action potential and depresses the rate of diastolic depolarization, thus suppressing spontaneous pacemaker activity (Zwaardmaker Libbrecht phenomenon) ; ${ }^{12}$ emergence of potential pacemakers and abnormal conduction pathways could then prevail. Any further increase in extracellular potassium can reduce the intracellular to extracellular $\mathrm{K}^{+}$concentration gradient and further suppress diastolic depolarization, resulting in cardiac asystole. Swales has reported bradycardia and $\mathrm{A}-\mathrm{V}$ block in a severely potassium depleted patient during the administration of $\mathrm{KCl}$ $50-60 \mathrm{mMol} / \mathrm{hr}^{14}$ (2) Furosemide has been shown to inhibit ATPase in rat kidneys after administration in vivo ${ }^{8}$ and in the turtle bladder. ${ }^{10}$ If myocardial ATPase activity were also inhibited by furosemide, loss of cellular $\mathrm{K}^{+}$and gain of $\mathrm{Na}^{+}$ could be expected. The intracellular to extracellular $\mathrm{K}^{+}$gradient would be further reduced by the acute elevation of serum potassium, resulting in a more positive resting membrane potential, which is closer to the threshold potential. The reduction of potential between resting membrane potential and threshold potential enhances cardiac excitability. ${ }^{1}$

Our data do not permit a clear interpretation of the effect of furosemide pretreatment on the renal excretion of acutely infused $\mathrm{KCl}$. The most obvious correlation is that acutely increased serum $\mathrm{K}^{+}$is accompanied by increased urine production and urinary excretion of potassium (Figure 1); furosemide pretreat- 
ment did not significantly alter renal excretion of $\mathrm{K}$ when comparing like-doses of $\mathrm{KCl}$ infused. Since total body potassium or intracellular potassium was not measured, we cannot assess the degree of potassium loss induced by furosemide. It is possible that these furosemide-pretreated animals did not have a significant cellular depletion of potassium; and/or the kidneys were not able to conserve acutely administered intravenous potassium, even if there was cellular depletion.

Other findings presented in this report deserve comment. Serum potassium was measured daily in the group during seven consecutive days of furosemide treatment. During the three treatment periods for each dog, we found the serum potassium value of corresponding days to be remarkably similar. Therefore the values for corresponding day of treatment were averaged. The small standard errors of means apparently support this impression (Table I). The arterial blood gases during these experiments were $\mathrm{Pa}_{\mathrm{O}_{2}} 13.6$ to $17.8 \mathrm{kPa}$ ( 122 to 134 torr) and $\mathrm{Pa}_{\mathrm{CO}_{2}} 4.0$ to $4.5 \mathrm{kPa}$ (30-33 torr). The $\mathrm{pH}$ was 7.29 to 7.40 . These values demonstrate adequate oxygenation and stable acid-base conditions. Hypoxia and changes in extracellular $\mathrm{pH}$ can significantly alter serum potassium concentration..$^{2.3}$

Our results suggest a cardiovascular stimulatory effect of potassium infusion, especially at serum $\mathrm{K}^{+}$concentrations of $6.9-9.1 \mathrm{mMol} / 1$. These data are compatible with the findings of Surawicz, et al, ${ }^{13}$ who showed an elevation in cardiac output and left ventricular $\mathrm{dP} / \mathrm{dt}$ within the range of a plasma- $\mathrm{K}^{+}$concentration of $7-9 \mathrm{mMol} / \mathrm{l}$ in dogs anaesthetized with pentobarbitone. However, they reported the lethal serum postassium concentration in these dogs to be $14-25 \mathrm{mMol} / \mathrm{I}$ which is considerably higher than those observed in the present study in which nitrous oxide-halothane anaesthesia instead of pentobarbitone was used.

The results of this study suggest that furosemide pretreatment in dogs reduces plasma potassium but not to a hypokalaemic level which might be considered clinically dangerous. However, furosemide-pretreated animals were less tolerant to the acute intravenous administration of $\mathrm{KCl}$. The kidneys did not conserve potassium during acute administration of $\mathrm{KCl}$ in furosemide-pretreated dogs. The data suggest that acute intravenous administration of potassium for repleting furosemide-induced hypokalaemia in dogs may not be effective and could be hazardous.

\section{SUMmary}

Twelve male mongrel dogs were used for this study; six were untreated (control) and six were given intravenous furosemide ( $1 \mathrm{mg} / \mathrm{kg}$ ) daily for seven consecutive days before each study. Each animal received intravenous $\mathrm{KCl} 0.8,1.6$ or $3.2 \mathrm{mMol} / \mathrm{kg} / \mathrm{hr}$ for one hour, but only one dose for each study and at least seven days were allowed between studies. The animals were given thiopentone for tracheal intubation and mechanically ventilated, maintaining a $\mathrm{Pa}_{\mathrm{CO}}$ of 4.0 to $4.5 \mathrm{kPa}$ (30-35 torr) and anaesthetized with nitrous oxide-oxygen and halothane.

Daily administration of furosemide reduced serum potassium from 4.48 to 4.09 $\mathrm{mMol} / \mathrm{l}$ with no significant change in serum sodium. A greater number of furosemide-pretreated animals (6 vs 3 ) developed cardiac dysrhythmias during nonlethal intravenous $\mathrm{KCl}$ at $0.8,1.6 \mathrm{mMol} / \mathrm{kg} / \mathrm{hr}$. The furosemide-pretreated group tended to succumb at a lower serum potassium concentration $(12.2 \mathrm{vs} 13.8 \mathrm{mMol} / \mathrm{l}$, 
$\mathrm{P}>0.05$ ) and developed earlier onset ( 44 vs $54 \mathrm{~min}, \mathrm{P}<0.05$ ) of cardiac standstill or ventricular fibrillation following intravenous $\mathrm{KCl}$ at $3.2 \mathrm{mMol} / \mathrm{kg} / \mathrm{hr}$. Cardiac output, heart rate and mean arterial pressure were significantly elevated during serum concentrations of $6.9-9.1 \mathrm{mMol} / 1$, while no statistically significant changes were observed for stroke volume and peripheral resistance. There were no significant differences of urinary potassium excretion between the untreated and treated groups when like doses of $\mathrm{KCl}$ were infused.

These data suggest that acute infusion of $\mathrm{KCl}$ in furosemide-pretreated dogs may not be an effective means of treating hypokalaemia and could be hazardous.

\section{RÉSUMÉ}

Cette étude portait sur douze chiens, soit un groupe contrôle de six chiens et un second groupe ayant reçu par voie intra-veineuse durant sept jours consécutifs, de la Furosemide à raison de $1 \mathrm{mg} /$ kilo.

Chacun de ces douze animaux fut soumis au protocole suivant : après une induction au Thiopentone, suivie d'intubation, l'anesthésie était maintenue avec un mélange de Protoxyde d'azote-Oxygène (60-40 pour cent) et Halothane à 1 pour cent. Un ventilateur mécanique maintenait la $\mathrm{Pa}_{\mathrm{CO}_{2}}$ entre 30 et 35 torr. Après stabilisation des paramètres respiratoires et cardiovasculaires, soit 45 à 60 minutes après le début de l'anesthésie, l'animal recevait une infusion de $\mathrm{KCl}$ à raison de 0.8 , de 1.6 et enfin de $3.2 \mathrm{mMol} / \mathrm{kg} /$ heure.

Les effets des différentes concentrations de $\mathrm{KCl}$ ont été étudiés au cours de séances séparées chez chacun des animaux, le délai entre les séances étant d'au moins une semaine.

La dose journalière de Furosemide a réduit de façon légère mais significative le taux sérique du potassium (de 4.48 à $4.09 \mathrm{mMol} /$ litre) mais n'a pas modifié significativement le sodium sérique.

L'incidence d'arythmies observées durant l'administration du $\mathrm{KCl}$ aux concentrations non mortelles ( 0.8 et $1.6 \mathrm{mMol} / \mathrm{kg} /$ heure) était plus élevée ( 50 pour cent) chez les chiens prétraités à la Furosemide que chez les chiens-contrôle. A la concentration mortelle $(3.2 \mathrm{mMol} / \mathrm{kg} /$ heure $)$, les chiens prétraités succombaient à un taux de potassium sérique plus bas $(12.2 \mathrm{vs} 13.8 \mathrm{mMol} / \mathrm{litre}, \mathrm{p}>0.05)$; de même, l'apparition d'asystolie ou de fibrillation ventriculaire survenait plus précocément chez les chiens prétraités ( 44 vs $54 \mathrm{~min}$ ).

Lorsque le taux sérique du potassium atteignait 6.9 à $9.1 \mathrm{mMol} / \mathrm{litre}$, on observait une élévation significative du débit cardiaque, de la fréquence et de la pression artérielle moyenne, ceci sans modification significative du volume d'éjection et de la résistance périphérique. L'excrétion urinaire du potassium n'était pas différente d'un groupe à l'autre.

Nos résultats indiquent que l'administration aigue de $\mathrm{KCl}$ chez des chiens ayant reçu de la Furosemide au préalable, n'est peut-être pas une façon efficace de traiter une hypokaliémie et qu'elle peut présenter des dangers.

\section{ACKNOWLEDGMENT}

The authors wish to thank Mrs. Vicky Larsen for the preparation of this manuscript. 


\section{REFERENCES}

1. Woopbury, J.W. Cellular electrophysiology of the heart, Handbook of Physiology, Section 2. Circulation 1: 237 (1962)

2. Scribner, B.H. \& Burneld, J.M. Interpretation of the serum potassium concentration. Metabolism 5: 468 (1956).

3. Wong, K.C., Wetstone, D., Martin, W.E., et al. Hypokalemia during anesthesia: the effects of d-tubocurarine, gallamine, succinylcholine, thiopental and halothane with or without respiratory alkalosis. Anesth. \& Analg. 53: 522 (1973).

4. Warner, H., Gardner, R., \& Tononto, A. Computer-based monitoring of cardiovascular functions in post-operative patients. Circulation (Suppl. II) 37:68 (1968).

5. Wong, K.C. The effect of acute hypokalemia and respiratory changes on cardiac excitability. American Society of Anesthesiologists Abstracts of Scientific Papers, p. 419 (October, 1974).

6. Wright, B.D. \& DiGiovanni, A.J. Respiratory Alkalosis, hypokalemia and repeated ventricular fibrillation associated with mechanical ventilation. Anesth. \& Analg. 48: 467 (1969).

7. Lawson, N.W., Butleh, G.H., \& RAY, C.T. Alkalosis and cardiac arrhythmias. Anesth. \& Analg. 52: 951 ( 1973).

8. Hook, J.B. \& Williamson, H.E. Lack of correlation between natriuretic activity and inhibition of renal Na-K activated ATPase. Proc. Soc. Exp. Biol. Med. 120: 358 (1965).

9. Bourgoignie, J., Kuahr, S., Yates, J., et al. Characteristics of ATPase system of turtle bladder epithelium. Am. J. Physiol. 217: 1496 (1969).

10. EBeL, $H$. Effect of diuretics on renal Na-K ATPase and adenyl cyclase. Naunyn-Schmiedeberg's Arch. Pharmacol. 281: 301 (1974).

11. Stason, W.B., Cannon, P.J., Heinemann, H.O., et al. Furosemide: A clinical evaluation of its diuretic action. Circulation 34: 910 (1966).

12. Surawicz, B. \& Gettes, L.S. Two mechanisms of cardiac arrest produced by potassium. Circulation Res. 12: 415 (1963).

13. Surawicz, B., Chlebus, H., \& Mazzoleni, A. Hemodynamics and electro-cardiographic effects of hyperpotassemia. Differences in response to slow and rapid increases in concentrations of plasma K. Am. Heart J. 73: 647 ( 1967 ).

14. Swales, J.D. Hypokalemia and the electrocardiogram. Lancet 2: 1365 (1964). 